\title{
Study of Some Biochemical Changes among Workers Occupationally Exposed to Phenol, Alone or in Combination with Other Organic Solvents
}

\author{
Magdy Youssef SHAMY*, Ragaa Mohammed EL GAZZAR, \\ Mohamed Ahmed EL SAYED and Alaa Morsi ATTIA
}

\author{
High Institute of Public Health, 165 El Horreya Avenue, Hadara, \\ Alexandria, Egypt
}

(Received May 23, 1994 and in revised form December 2, 1994)

\begin{abstract}
The present study was aimed for the effects of exposure to multiple organic solvent vapors in comparison with single exposure to phenol. It included 20 workers exposed to phenol alone and 32 workers of combined exposure to phenol, benzene, toluene and methyl ethyl ketone. A control group of $\mathbf{3 0}$ subjects was also included. The levels of transaminases, total proteins, prothrombin time, bleeding time, clotting time, fasting blood sugar, serum creatinine and some trace elements (copper, zinc, iron, magnesium, manganese and calcium) were determined in blood together with a complete blood picture. Urine samples were analyzed for phenol, hippuric acid and methyl ethyl ketone. The effects of combined exposure did not differ from that of exposure to phenol alone concerning the majority of the tested parameters. Only the levels of platelets count, prothrombin time, eosinophils, copper and iron have been affected by combined exposure in a probably additive manner.
\end{abstract}

Key words: Phenol - Benzene - Methyl ethyl ketone - Toluene

\section{INTRODUCTION}

Organic solvents have a wide range of applications. Exposure to organic solvents is an eminent risk factor in work place ${ }^{1)}$. Inhalation of organic solvents can cause injury to several internal organs of the human body. The risk of injury

* To whom correspondence must be addressed. 
depends on the concentration of the substance in the respirable air, the duration of exposure and whether it is present alone or in mixtures ${ }^{2}$. However, studying the effects of multiple exposure is a relatively unexplored area of occupational health.

Chronic phenol poisoning in man is characterized by systemic disorders such as digestive, nervous and mental disorders ${ }^{3)}$. Also, liver enlargement and elevated levels of serum lactic dehydrogenase (LDH), serum alanine aminotransferase (ALT) and serum aspartic aminotransferase (AST) were observed among workers occupationally exposed to phenol ${ }^{4}$. An exact occupational appraisal of phenol toxicity in man is sometimes difficult because it is usually found in mixtures with other solvents. Such combinations may exert an effect different from that caused by exposure to phenol alone ${ }^{5)}$.

For solvents which generally affect the same organ, the conservative assumption for their combined effect is additivity6). Other possibilities such as antagonism, synergism or potentiation are also expected. The concentration of each chemical in a mixture seems to play a key role in the interaction of multiple chemical exposure. Such interaction was taken to be negligible when the extent of exposure remains at a minimal degree, i.e., in the range of the threshold limit values $^{7)}$.

This study has been carried out to detect the biochemical effects resulting from occupational exposure to phenol when it is combined with other organic solvents.

\section{Materials ANd Methods}

The present study includes a total number of 82 male subjects from an oil refining plant located in the city of Alexandria. They were selected randomly and have been divided into three groups:

Group I: Workers exposed to phenol alone $(n=20)$, during aromatic extraction from distillates containing aromatics, wax, oil and impurities. The time weighted average exposure according to the factory records was $5.4 \mathrm{ppm}$.

Group II: Workers with combined exposure to phenol, benzene, toluene and methyl ethyl ketone (MEK) $(n=32)$. The time weighted average exposure according to the factory records was $4.7 \mathrm{ppm}$ for phenol, $0.7 \mathrm{ppm}$ for benzene, 220 ppm for toluene and $90 \mathrm{ppm}$ for MEK.

Group III: A reference group of 30 subjects selected from the administrative departments. They were located in a separate building far from any exposure. They had no history of exposure to organic solvents, but with the same demographic characters like age, educational status and socioeconomic status ... etc, as the exposed workers.

Fasting blood samples were collected from each subject by vein puncture at the end of the shift of the last working day of the week. A part of the blood was centrifuged and the serum was separated for the analysis of transaminases (AST 
and ALT), total proteins, prothrombin time, bleeding time, clotting time, fasting blood sugar (FBS) and serum creatinine using commercial kits. Also, the levels of some trace elements in serum have been determined by atomic absorption spectrophotometry ${ }^{8}$. These were: copper $(\mathrm{Cu})$, zinc $(\mathrm{Zn})$, iron $(\mathrm{Fe})$, magnesium $(\mathrm{Mg})$, manganese $(\mathrm{Mn})$ and calcium $(\mathrm{Ca})$. The rest of the blood was used for obtaining a complete blood picture using the standard methods ${ }^{9}$. The measured items in blood are presented in Table 3.

Spot urine samples were obtained from each subject for the determination of the biological indices of exposure. For phenol and/or benzene exposure, the levels of urinary phenol have been determined ${ }^{10)}$. Analysis of hippuric acid and methyl ethyl ketone in urine was carried out to assess the exposure to toluene and methyl ethyl ketone respectively ${ }^{11,12)}$. The concentrations of all urinary parameters were referred to the creatinine content.

Statistical analysis of the obtained data has been carried out using the one way ANOVA and the Scheffe test. The level of significance was taken at $5 \%$ or $1 \%$ according to the obtained value.

\section{RESULTS}

The population characteristics and the biological indices of exposure among the different groups of examined subjects are presented in Table 1. No statistically significant difference has been found between the mean ages of the different groups and the durations of exposure between the two groups of exposed workers. All the biological indices were higher among the exposed groups than the control subjects $(\mathrm{p}<0.01)$.

The mean levels of FBS, ALT, AST, total proteins, serum creatinine, prothrombin time, bleeding time and clotting time among the different groups of examined subjects are shown in Table 2. Workers exposed to phenol either alone or in combination with the other organic solvents showed statistically significant higher levels ( $p<0.05,0.01)$ of ALT, AST and clotting time, and lower levels $(p<0.01)$ of serum creatinine than control subjects. Prothrombin time was found to increase significantly only among workers exposed to phenol with other organic vapors $(\mathrm{p}<0.01)$. No variations could be detected in the mean levels of FBS, total proteins and bleeding time between the different groups of examined subjects.

Table 3 presents the mean levels of the hematological findings among the different groups of examined subjects. Workers exposed to phenol either alone or in combination with organic solvents showed statistically significant higher levels ( $\mathrm{p}<0.05,0.01$ ) of hemoglobin, hematocrit, color index, $\mathrm{MCH}, \mathrm{MCV}$, basophils and neutrophils and lower levels $(\mathrm{p}<0.01)$ of monocytes than the control subjects. Workers exposed to a combination of phenol and other organic solvents showed a statistically significant decrease $(p<0.05,0.01)$ in the mean levels of platelets count and eosinophils. No changes have been detected in the levels of 
Table 1. Population characteristics and biological indices of exposure among the three groups of examined subjects.

\begin{tabular}{|c|c|c|c|c|c|c|}
\hline & \multicolumn{4}{|c|}{ Exposed workers } & \multicolumn{2}{|c|}{ Control subjects } \\
\hline & \multicolumn{2}{|c|}{ Group I } & \multicolumn{2}{|c|}{ Group II } & & \\
\hline & \multicolumn{2}{|c|}{20} & \multicolumn{2}{|c|}{32} & \multicolumn{2}{|c|}{30} \\
\hline & Mean & SD & Mean & SD & Mean & $\mathrm{SD}$ \\
\hline Age (years) & 35.15 & 5.66 & 37.90 & 6.80 & 37.30 & 3.64 \\
\hline $\begin{array}{l}\text { Duration of } \\
\text { exposure (years) }\end{array}$ & 13.15 & 6.55 & 14.34 & 6.05 & - & - \\
\hline $\begin{array}{l}\text { Phenol in urine } \\
\text { (mg/g creatinine) }\end{array}$ & $68.60^{* *}$ & 47.06 & $53.74^{* *}$ & 27.20 & 11.54 & 4.70 \\
\hline $\begin{array}{l}\text { Hippuric A. in urine } \\
\text { (g/g creatinine) }\end{array}$ & - & - & $4.70^{* *}$ & 1.49 & 1.08 & 0.22 \\
\hline $\begin{array}{l}\text { MEK in urine } \\
\text { ( } \mathrm{mg} / \mathrm{g} \text { creatinine) }\end{array}$ & - & - & $2.75^{* *}$ & 1.00 & - & - \\
\hline
\end{tabular}

$* \mathrm{p}<0.05, * * \mathrm{p}<0.01$ : Significant difference against Control group.

Group I: Workers exposed to phenol only.

Group II: Workers exposed to phenol, benzene, toluene and MEK.

Table 2. Mean levels of FBS, ALT, AST, total proteins, serum creatinine, prothrombin time, bleeding time and clotting time among the three groups of examined subjects.

\begin{tabular}{|c|c|c|c|c|c|c|}
\hline & \multicolumn{4}{|c|}{ Exposed workers } & \multicolumn{2}{|c|}{ Control subjects } \\
\hline & \multicolumn{2}{|c|}{ Group I } & \multicolumn{2}{|c|}{ Group II } & & \\
\hline $\mathrm{n}$ & \multicolumn{2}{|c|}{20} & \multicolumn{2}{|c|}{32} & \multicolumn{2}{|c|}{30} \\
\hline & Mean & SD & Mean & SD & Mean & SD \\
\hline FBS (mg/dl) & 85.62 & 15.12 & 86.47 & 28.91 & 78.35 & 31.78 \\
\hline ALT $(\mathrm{U} / \mathrm{ml})$ & $24.50^{*}$ & 4.11 & $22.10^{*}$ & 6.93 & 15.81 & 14.92 \\
\hline AST $(\mathrm{U} / \mathrm{ml})$ & $27.06^{* *}$ & 16.87 & $23.42^{* *}$ & 7.32 & 14.71 & 10.70 \\
\hline T. proteins $(\mathrm{g} / \mathrm{dl})$ & 7.91 & 1.14 & 7.26 & 1.70 & 7.74 & 0.79 \\
\hline S. creatinine $(\mathrm{mg} / \mathrm{dl})$ & $0.85^{* *}$ & 0.20 & $0.82^{* *}$ & 0.17 & 0.99 & 0.20 \\
\hline $\begin{array}{l}\text { Prothrombine time } \\
(\mathrm{sec})\end{array}$ & 14.53 & 2.86 & $16.20^{* *}$ & 2.74 & 11.77 & 0.67 \\
\hline Bleeding time $(\min )$ & 2.04 & 0.62 & 2.16 & 0.58 & 1.94 & 0.33 \\
\hline Clotting time $(\mathrm{min})$ & $6.13^{* *}$ & 0.82 & $5.83^{* *}$ & 1.27 & 4.06 & 0.46 \\
\hline
\end{tabular}

$* \mathrm{p}<0.05, * * \mathrm{p}<0.01$ : Significant difference against Control group.

Group I: Workers exposed to phenol only.

Group II: Workers exposed to phenol, benzene, toluene and MEK. 
Table 3. Mean levels of hematological findings among the three groups of examined subjects.

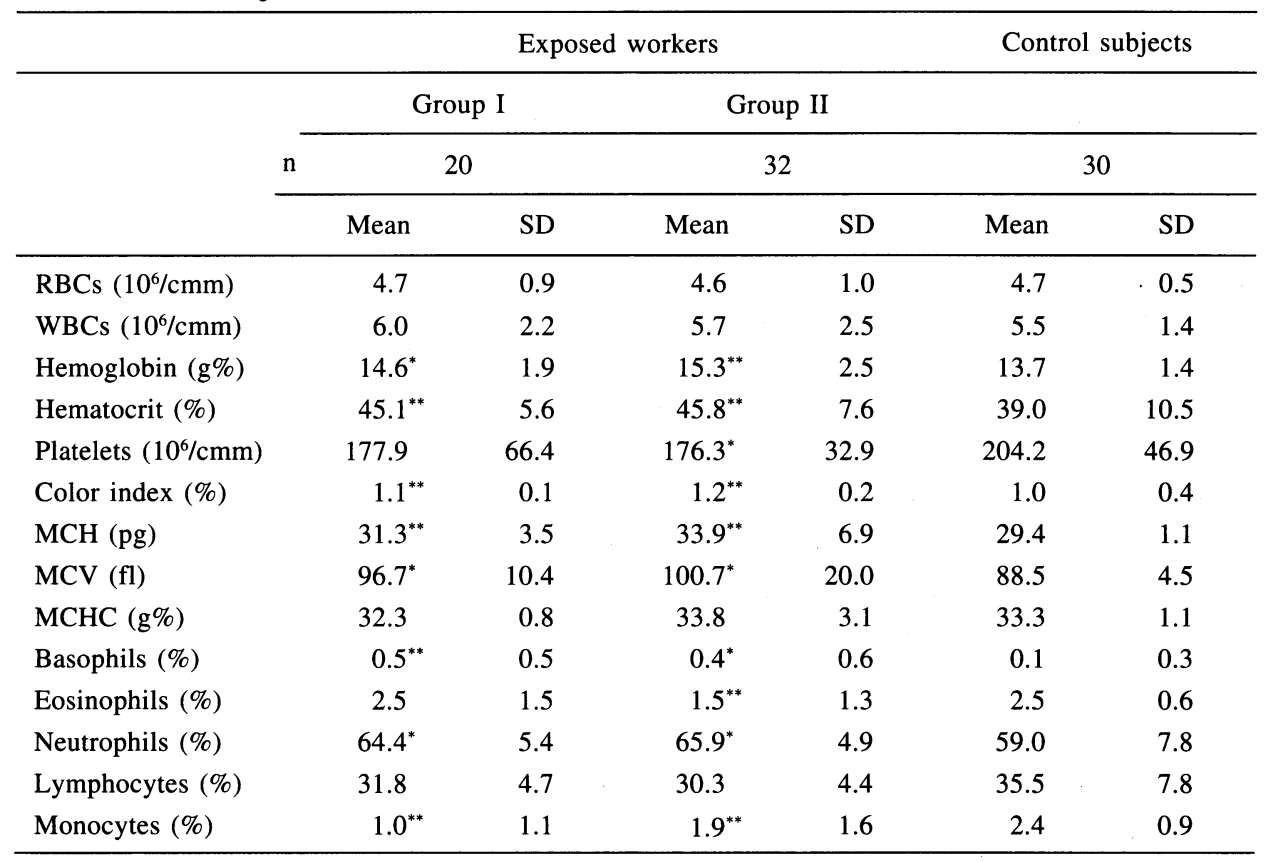

$* \mathrm{p}<0.05, * * \mathrm{p}<0.01$ : Significant difference against Control group.

Group I: Workers exposed to phenol only.

Group II: Workers exposed to phenol, benzene, toluene and MEK.

RBCs, WBCs, MCHC and lymphocytes.

The mean levels of some trace elements in serum among the different groups of examined subjects are shown in Table 4. Statistically significant higher levels $(\mathrm{p}<0.01)$ of $\mathrm{Mg}, \mathrm{Mn}$ and $\mathrm{Ca}$ were found among workers exposed to phenol either alone or in combination with the other organic solvents, while statistically significant lower levels of copper and iron $(p<0.05,0.01)$ were found only among workers exposed to phenol in combination with other organic solvents. No statistically significant variations could be detected in the levels of urinary $\mathrm{Zn}$ between the different groups of examined subjects.

\section{Discussion}

Health effects and/or biochemical changes due to exposure to single organic solvents are mentioned abundantly in literature, but only limited information is available on the effects of exposure to multiple organic solvents.

The levels of exposure to phenol are relatively similar in both groups of ex- 
Table 4. Mean levels of some trace elements in serum among the three groups of examined subjects.

\begin{tabular}{|c|c|c|c|c|c|c|c|}
\hline & & \multicolumn{4}{|c|}{ Exposed workers } & \multicolumn{2}{|c|}{ Control subjects } \\
\hline & & \multicolumn{2}{|c|}{ Group I } & \multicolumn{2}{|c|}{ Group II } & & \\
\hline & \multirow[t]{2}{*}{$\mathrm{n}$} & \multicolumn{2}{|c|}{20} & \multicolumn{2}{|c|}{32} & \multicolumn{2}{|c|}{30} \\
\hline & & Mean & SD & Mean & SD & Mean & SD \\
\hline Copper $(\mu \mathrm{g} / \mathrm{dl})$ & & 94.2 & 30.4 & $91.1^{*}$ & 34.1 & 109.2 & 24.8 \\
\hline Zinc $(\mu \mathrm{g} / \mathrm{dl})$ & & 89.3 & 31.9 & 99.2 & 41.9 & 96.5 & 19.2 \\
\hline Iron $(\mu \mathrm{g} / \mathrm{dl})$ & & 131.7 & 33.9 & $117.5^{* *}$ & 36.5 & 140.0 & 22.1 \\
\hline Magnesium $(\mu \mathrm{g} / \mathrm{dl})$ & & $2.3^{* *}$ & 0.5 & $2.5^{*}$ & 0.5 & 1.9 & 0.5 \\
\hline Manganese (mg/dl) & & $0.4^{* *}$ & 0.3 & $0.5^{* *}$ & 0.3 & 0.2 & 0.3 \\
\hline Calcium (mg/dl) & & $11.9^{* *}$ & 2.0 & $11.5^{* *}$ & 1.9 & 9.8 & 0.9 \\
\hline
\end{tabular}

$* \mathrm{p}<0.05,{ }^{* *} \mathrm{p}<0.01$ : Significant difference against Control group.

Group I: Workers exposed to phenol only.

Group II: Workers exposed to phenol, benzene, toluene and MEK.

posed workers: $5.4 \mathrm{ppm}$ for workers exposed to phenol alone and $4.7 \mathrm{ppm}$ for those exposed to phenol with other organic solvents. The low levels of benzene in air $(0.7 \mathrm{ppm})$ supports the view that the levels of urinary phenol found among workers exposed to a combination of organic solvents is mainly due to phenol exposure. In general, the higher levels of the biological indices of exposure among the exposed population in comparison to the tentative biological TLVs reported in literature ${ }^{13)}$ suggest that these workers are exposed to considerable amounts of organic solvents. Therefore, an interaction between the different types of organic solvents, especially the potentiated action, is expected. This type of interaction has been reported between benzene and toluene ${ }^{14)}$, as well as between MEK and various hydrocarbon compounds ${ }^{15}$.

Most of organic solvents are well known hepatotoxic compounds. AST and ALT are the enzymes most often measured for liver functions evaluation ${ }^{16)}$. These enzymes have been reported to be affected by exposure to benzene ${ }^{17)}$, toluene ${ }^{18)}$ and phenol ${ }^{19)}$. In the present study, the levels of AST and ALT were found to be elevated among workers exposed to phenol either alone or in combination with other organic solvents. This means that the effect of phenol exposure on these enzymes has not been altered by the combination of phenol with benzene, toluene and MEK. However, the prothrombin time, which is reported to be prolonged in liver injury ${ }^{20)}$ was not affected by exposure to phenol with other organic solvents. This result suggests the different impact in the multiple organic vapors exposure to liver than that of single phenol exposure.

Concerning kidney functions, lowered creatinine levels have been observed in workers with excessive solvent exposure ${ }^{21)}$. The same results have been obtained 
in the present study among both groups of exposed workers.

Literature reported changes in the blood picture of workers exposed to organic solvents ${ }^{21-23)}$. Exposure to toluene was found to decrease the mean corpuscular hemoglobin concentration (MCHC) and the percentage of basophils ${ }^{21)}$ and to increase the hemoglobin levels ${ }^{22}$, while benzene exposure caused leucopenia and hypohemoglobinemia ${ }^{23)}$. In the present study, exposure to a combination of organic solvents altered the blood picture of the exposed workers in a similar manner as exposure to phenol alone, except that a decrease in platelets count and in percentage of eosinophils have been found among workers exposed to multiple organic solvents.

Liver represents the storage organ for most of trace elements. Therefore, it is not surprising that in various liver disorders, one encounters metabolic changes in respect to these microelements ${ }^{24}$. The present study revealed that workers exposed to phenol either alone or in combination with other organic solvents showed increased levels of magnesium, manganese and calcium. This is in accordance with literature which reported increased manganese levels in serum after liver injury ${ }^{20)}$ and elevated values of serum magnesium and serum calcium among workers exposed to toluene ${ }^{25)}$. Exposure to combined organic solvents and not to phenol alone decreased the levels of both serum copper and iron. The metabolism of copper and iron are known to be interdependable. Copper depletion leads to a failure in the use of ferritin iron which accumulates in liver ${ }^{20)}$.

It can be concluded that the effect of occupational exposure to phenol combined with benzene, toluene and MEK differs from that of occupational exposure to phenol alone especially in what the liver is involved, as far as, the levels of prothrombin time, serum copper and serum iron reflect. More attention should be paid to the health effects of combined chemical exposure.

\section{REFERENCES}

1) Irma A. Exposure to organic solvents. Newsletter 1990; 4: 1-6.

2) Pernilla K. Exposure to organic solvents. Pharmacodynamics and pharmacokinetics approach. Newsletter 1989; 2: 6-14.

3) Merliss R. Chronic phenol exposure. J Occup Med, 1972; 14: 155-59.

4) Smart R. The liver: a target and a tool in phenol toxicity. Mol Pharmacol 1984; 26: 105-8.

5) WHO Health effects of combined exposure in the work environment. Technical report series, 662, Geneva, Switzerland. 1981; pp. 47-52.

6) William D, James V, Robert B, Fred C, Lowry K. Combined exposure to organic solvents. J Occup Med Assoc 1987; 29: 877-84.

7) Sato A, Nakazima T. Dose-dependent metabolic interaction between benzene and toluene in vivo and in vitro. Toxicol Appl Pharmacol 1979; 48: 249-56.

8) Shimadzu flame atomic absorption manual. Standard analytical methods. 1990.

9) Docie J, Lewis S. Practical hematology, 5th edition, London. pp. 236-39.

10) Risford S, Lloyd D. A colorimetric method for estimation of phenol in urine. Brit J Ind Med 1965; 21: 26-32.

11) Leonard D, Pagnotto S, Lionel M, Lieberman M. Urinary hippuric acid: a sensitive indicator for 
toluene exposure. Amer Ind Hyg Assoc J 1967; 28: 129-35.

12) Snell F, Snell C. Colorimetric methods for analysis. vol. 2. Second edition, McGraw Hill Publications, New York, USA. 1987; pp. 341-47.

13) Lauwerys R. Biological monitoring of exposure to industrial chemicals. Biomedical publications. California, USA. 1982 ; pp. 367-72.

14) Kahan W. Simultanous exposure to benzene and toluene. Biochem Pharmacol 1984; 1: 200913.

15) Brown E, Hewitt W. Dose-response relationships in ketone-induced potentiation of chloroform hepato and nephro toxicity. Toxicol Appl Pharmacol 1984; 76: 437-41.

16) Innerfield F. Enzymes in clinical chemistry. McGraw Hill Publications. New York, USA. 1960; pp. 465-71.

17) Droz P, Cumberland W. Benzene hepatotoxicity. Brit J Ind Med 1989; 46: 547-52.

18) Lloyd W, Decoufle P, Salvin L. Biological monitoring of toluene exposure. J Occup Med 1977; 19: 543-49.

19) Schaper K. Histological and biochemical study of chronic phenol toxicity. Anesthesiol Reanimat 1981; 6: 73-81.

20) Tiez N. Fundamentals of clinical chemistry. Third edition, W.B. Saunders Company, USA. 1987; pp. 257-58.

21) Winchester R, Madjar V. Nephrotoxicity of organic solvents. Ann Occup Hyg 1986; 1: 30710.

22) Elofsson S, Gamberale F, Hindmarsh T, Iregren A, Isaksson A, Johnson I, Knave B, Lydahl E, Mindus P, Persson R, Philipson B, Steby M, Struve G, Söderman E, Wennberg A, Widén L. Exposure to organic solvents. A cross-sectional epidemiologic investigation on occupationally exposed car and industrial spray painters with special reference to the nervous system. Scand J Work Environ Health 1980; 6: 239-73.

23) Aksoy M. Hematological effects of benzene exposure. Trop Rev Haematol 1982; 2: 105-9.

24) Fikry A. Gastroenterology. Part I. El Maaref Establishment, Alexandria, Egypt. 1978; pp. 1068.

25) Weinstein S, Scottolini A, Bhagavan N. Trace elements in blood and exposure to organic solvents. Clin Chem 1985; 31: 330-36. 